\title{
International Academic Mobility as a Capacity Building Factor in Higher Education
}

\author{
Dabney-Fekete, Ilona Dora ${ }^{1}$
}

Recommended citation:

Dabney-Fekete, I. D. (2020). International Academic Mobility as a Capacity Building Factor in Higher Education. Central European Journal of Educational Research, 2(1), 82 - 91.

\begin{abstract}
International academic mobility means the teaching or research activity of higher educational instructors or researchers, which spans a couple of days or a few months, during which individual professional growth, the establishment of international cooperation and networks, personal relations and friendships may develop. It is also considered to be a fundamental necessity for building capacity and an outstanding supremacy, even if a country's academic resources are modest. Thus it is crucial to gain information about its current and actual state, quality, standards, struggles and the direction it is heading towards. As a part of a bigger research study, we wanted to know how international academic mobility, used for capacity building, changes over time, and whether country-specific features and patterns could be traced. In this present study we made an attempt to uncover the international activity based on the academic mobility of the full-time instructors at two Hungarian higher educational institutions. One of them is a large university that plays a leading role in internationalization. The other is a dynamically developing regional knowledge center. We examined the instructors of two faculties from the first, and everybody from the regional knowledge center, since it is smaller in size. Altogether 210 instructors responded to our 60 questions in the survey. The surveys were processed in the SPSS statistical analysis program. Concerning the examined discussions, categories and proposed topics, our research was built upon two previously carried out investigations - a Hungarian and a Norwegian one. We found that in Hungary in the given time period (2012-2014), the instructors with the strongest international activity were: 1 . the men; 2 . those who held higher academic positions; 3 . those who were married or were in a relationship; and 4 . who were from the field of social science.
\end{abstract}

Keywords: capacity building, internationalization, higher education, academic mobility, international cooperation

\section{Introduction}

\subsection{Internationalization of higher education}

Internationalization has reconstructed the scenery of higher education in every corner of the world, and it is a factor that cannot be ignored. In the new millennium the higher educational institutions in many countries start to realize even to a greater extent that globalization brings pressure to bear on the way universities achieve their goals, and that it browbeats them into meeting the demands of the state's evaluation and requirements - both on institutional and individual levels. For these higher educational institutions participating in the processes of globalization is not optional, and not only on national levels, but it is an urge for change and adaptation on the institutions' and individual's level as well. That is the reason why internationalization is of key importance, since the joining of the international academic value-chain and the intentional expansion of trans-border

\footnotetext{
${ }^{1}$ Eszterházy Károly University, Eger, Hungary; fekete.ilona@uni-eszterhazy.hu, feketeid@gmail.com
} 
cooperation do not only improve the quality of training but they are also key to the competitiveness of knowledge and to being measured in an international academic environment.

Teichler (1999) defines internationalization in higher education as an unstoppable trend that we can either take it as a challenge reacting to it as such, or we can miss out on it. Enders (2004; Enders-Fulton 2002) claims that countries may differ in how they respond to said challenge, and in how they achieve their goals. Therefore, the starting point of a given country is also of great importance. Based on these responses, four types of internationalization were found (Enders-Teichler 1995). The first is the so-called "would-be" internationalization. In these countries, international activity is very much supported both by the institution and the individual. However, they cannot find partners from among the representatives of bigger countries. In the states that are characterized by "life-or-death" internationalization, academics cannot gain respect at home unless they are internationally active and visible. In other countries the national academic market is strong and significant enough to be an arena on its own. Nevertheless, international activities are also feasible options. The authors call this "two-arena" internationalization. The last type, the "one-way" internationalization is typical of English-speaking countries, where only those studies count that were published in English. Normally these are target countries for academic mobility.

What is typical of internationalization "competition" appearing in higher education is that the non-material goods, like knowledge, creativity or social capital are much more appreciated and thus they become the catalysts of development (Papanek 2006). Despite the benefits internationalization has, it also evokes fear in many an instructors, since it carries in itself the possibility of disappointment and disillusionment. Presenting one's scientific findings to an international academic community can be intimidating, for the number of (sometimes ruthless) critiques multiplies exponentially.

\subsection{International academic mobility}

Internationalization in higher education can be looked upon as a possible answer given to globalization (Knight 2003; Knight 2013; Knight-De Wit 2018), and the increasing importance of academic cooperation and international mobility can be regarded as its two main elements. The latter is considered to be a fundamental necessity for building capacity and an outstanding supremacy, even if a country's academic resources are modest (Jacob-Meek 2013; Morley et al. 2018). That could be a reason why academic mobility is very much supported at policy levels, and also why researchers and instructors, on the path to reaching a knowledge economy, are favored resources (Yang 2020), even if more and more researchers in the field articulate their concerns about the phenomenon on a grand scale (Jacob-Meek 2013; Knight 2013; Siekierski et al. 2018; Morley et al. 2018, Yang 2020).

International academic mobility means the teaching or research activity of higher educational instructors or researchers, which spans a couple of days or a few months, during which individual professional growth, capacity building, the establishment of international cooperation and networks, personal relations and friendships may develop. In higher educational institutions, personal academic progress and achievement is closely connected to internationalization. These are won through gaining collaboration experience via being a guest lecturer, attending conferences abroad, or winning scholarships and grants. We considered it a foundation stone that the international activity of instructors can appear on several levels, and that it definitely cannot be regarded as the "personal affair" of either the academic or the institution, at which they are employed. Not only the individual or the higher educational institution supporting them benefits from the academic's international mobility, but also there are relevant social aims (O'Hara 2009). On the one hand, due to the fact that instructors gain and share knowledge amid their academic mobility, they further broaden national scientific knowledge, a possible element of international competitiveness. And on the other, the aforementioned knowledge that they acquired abroad can be translated into the national language and interpreted for national colleagues. And lastly, they can also be of influence on those forming the future academic elite and the decision makers (O'Hara 2009; Dusa 2017). Regarding the types of individual academic mobility, we can differentiate between short-term missions, which expand only 
through the period of a conference presentation or a meeting that lasts for a couple of days, and longterm ones, which cover one or two, sometimes more semesters. Besides these two types we can talk about regular academic mobility for a predetermined period of time, which means that the instructor holds a position in two countries' higher educational institutions and divides their time up equally between the two universities (Vlasceanu 1987).

When we talk about international mobility from the aspect of economy, it is important to note the factors that are manifested as national economic interest. Numerous researches and studies are published on the forces enhancing economy, out of which several mention the accumulation of knowledge as the most central force. This manifests itself through the creation of new knowledge that is innovation (Sebestyén 2011), which is interactive, due to its nature. Thus it is a procedure that uses the creativity, professional experience and past knowledge of the participants and is based on cooperation. Closely linked to this is knowledge capital. The knowledge capital of a higher educational institution consists of the structural and the social capital of the individual, as well as the human capital that involves the instructor's experiences, knowledge, skills, competences, education and the information they possess. It is rather challenging to measure. However, we can see the manifestations and results of it. Thus not only the existence but the extent of it can be quantified - for instance through the number of publications, scholarships, conference presentations, etc. The real value of it, however, can only be detected when an instructor leaves the system, taking their knowledge, skills and networks with them.

Another important concept of international mobility examined from the side of economy is the knowledge broker. According to Simmel (1992) there are certain social role players, driven either by their own or by a group's interest, who serve as mediators between individuals and groups who otherwise would never meet. They call them brokers. Taking the theory of social capital and taking Simmel's idea one step further, the knowledge broker is someone who by being a member of multiple communities, enhances the exchange of knowledge between the groups, promoting the creation of new knowledge and supporting changes (Sverrisson 2001; Kakihara- Sorensen 2002; Meyer 2010, Pusztai-Fekete et al. 2016).

In Hungary, just like in other post-socialist countries, knowledge brokers played an important role during the political change. Politically active and at the same time educationally outstanding young academics had the chance to apply for a grant or scholarship to Northern European countries or the United States. They returned with the knowledge of how democracy works, and the acquired language skills lifted one part of them into high political, economic or academic positions after the Change of Regime (1989). This latter group brought with themselves the international theories, and research and publication practices (Pusztai-Fekete et al. 2016).

\section{Research Design and Methods}

Considering that academic mobility is looked upon as a keystone for academic development and capacity building, it is crucial to gain information about its current and actual state, quality, standards, struggles and the direction it is heading towards. As a part of a bigger research study, we wanted to know how international academic mobility, used for capacity building, changes over time, and whether country-specific features and patterns could be traced.

Thus based on two former projects, we carried out a research (Dabney-Fekete 2018), the first part of which was between 2012 and 2014, by involving the full-time instructors of two higher educational institutions in Hungary. One of them is a large university that plays a leading role in internationalization, and it has several faculties, as well as prominent and expanded national and international cooperation networks. The other is a dynamically developing regional knowledge center that looks back on several centuries of tradition, and which is culturally very much embedded in its environment. Among its declared aims the increasing expansion of international collaboration, both on the student and instructor levels, can be found. Due to limited financial material, and also to the direction defined by the research, we were unable to interview the entirety of the two institutions, thus we examined the instructors of two faculties - the Humanities and the Medical Faculties - from 
the large university, and everybody from the regional knowledge center, since it is smaller in size. Altogether 210 instructors responded to our 60 questions in the survey - 70 out of the 259 at the Faculty of Humanities (FH), 71 out of the 243 at the Faculty of Medicine (FM), and 69 out of 248 at the regional knowledge center (RKC). The balanced ratio allowed us to compare the three. We prepared a full-spectrum survey, during which we encountered several obstacles. These predominantly derived from the distrust that in the academic field is mostly due to the requirement and rating system. Still, $25-26 \%$ of the distributed questionnaires were filled out and returned, which is a rather acceptable percentage, as we see similar tendencies with several previous Hungarian examinations (Pusztai 2007; Kozma-Fényes-Tornyi 2007). However, the surveys were processed in the SPSS statistical analysis program. All things considered, it was not our aim to show how one higher educational institution was better than the other, but simply to gather data on international academic mobility samples from multiple institutes. All in all, we deem our research to be an important building block to educational research as a whole, since successful data collection among faculty members and instructors in and of itself is scarce.

In our research we relied on the findings of a Hungarian (Viszt 2004) and a Norwegian (Smeby-Trondal 2005) test. We found the selection of the different types of academic mobility they used very useful, the questions raised in connection with the phenomenon highly pragmatic. Hence by using those same categories and investigating the same problems, the ground for comparison was already given. Furthermore, Norway, just like Hungary, has a unique official language that is spoken only by a few people, only a bit more than 4.5 million. If we count only the population and not the vast territory of the country, we can say that it is small. Researches (Luukkonen et al. 1992; Hakala 1998; Smeby-Gorniotzka 2008) prove that smaller countries play a more active role on the international stage, which is more likely due to the fact that the number of national cooperation and partners are limited, thus publicity and finding one's way have to be looked for on a wider and more colorful "market" (European Commission 1997).

During the Hungarian inquiry (Viszt 2004) made in 45 research centers in Hungary - state and private universities - the researchers wanted to know the extent of international academic mobility in our country (one of the target countries), and how these vary depending on the different fields of science, and what exact reasons are mentioned for not taking the opportunity to be internationally mobile. The Norwegian study (Smeby-Trondal 2005) that was carried out in 1981 and then repeated in 1990 and 2000, among the instructors of four universities, focused basically on the same topics: the intensity of the different forms of mobility in the given sample, the directions of them, and whether they are specific to a certain field of study.

\section{Results}

In our research, based on the categorization used by these studies, we made an attempt to measure the extent of academic mobility of the instructors in our sample. For that, we created the international activity index. Viszt (2004) and the Norwegian researchers (Smeby-Trondal 2005) examined four activities, regarded as types of mobility: participation in international conferences, attending academic scholarships, guest teaching, and being a part of international cooperation. We assigned a number to each of these activities according to the instructors: one, if the specific instructor has already been abroad with the certain type of activity, and zero, if he has not yet. After that we added up these four variables and examined the international activity index, where 0 and 1 inevitably show that the international activity of the instructor is poor (that is inactive), since out of the four academic projects they have only participated in maximum one. A number 2 or 3 denotes stronger activity, while a 4 meant an outstanding (active) stage.

In our sample we found that most of the instructors have a 1-4 activity level (Table 1), which naturally does not give us a full-spectrum view, especially not on the higher levels, since at this point we could only register the presence of or lack of activity, but not the frequency of it. 
Table 1. International activity of the instructors $(\mathrm{N}=210)$

\begin{tabular}{cc}
\hline level of international activity & $\mathbf{\%}$ \\
\hline 0 & 14,5 \\
1 & 21,7 \\
2 & 21,7 \\
3 & 26,6 \\
4 & 15,5 \\
\hline
\end{tabular}

We also compared our index to a couple of other variables to see which factors influence it the most. The international activity based on gender unambiguously is significant: women show a proportionately weaker activity level than men. This supports Schneider's (2009) theory that there is a very definite nexus between motherhood and mobility, that is the bringing together of the parental role and one's career is extremely difficult. Women are less mobile due to their tasks and duties they have to complete within the family as mothers.

Regarding academic status we found, as was expected, that the instructors on higher levels are internationally more active. The longer one is on the field, and the higher position they hold, the more likely their international activity index is stronger. However, what surprised us was that among the assistant lecturers we could hardly detect any international activity, the number of those who had not participated in any form of mobility is high (Table 2). We had assumed that the young, ambitious colleagues would be the ones who, due to their career-building plans and more secure foreign language knowledge, wanted to prove themselves the most on the international academic stage, and that international mobility would be seen both as a challenge and an adventure for them.

Table 2. International activity of instructors based on academic status $(\% ; \mathrm{N}=210)$

\begin{tabular}{lccccc}
\hline \multicolumn{1}{c}{ status ** } & $\mathbf{0}$ & $\mathbf{1}$ & $\mathbf{2}$ & $\mathbf{3}$ & $\mathbf{4}$ \\
\hline assistant lecturer & $\underline{\mathbf{2 8 , 9}}$ & 26,3 & 19,7 & 17,1 & 7,9 \\
assistant professor & 7 & 19,3 & 21,1 & $\underline{\mathbf{3 8 , 5}}$ & 14 \\
associate professor & 1,9 & 19,2 & 23,1 & 30,8 & $\underline{\mathbf{2 5}}$ \\
professor & 6,3 & 18,8 & 25 & 18,8 & $\underline{\mathbf{3 1 , 3}}$ \\
\hline
\end{tabular}

The level of significance of connection: ${ }^{* *} p<0,01$. The underlined values point to the fact that considerably more instructors ended up in these cells than what would have been in case of a random arrangement.

We also wanted to take a closer look at the international activity index from the point of view of marital status. We were interested in whether the findings of the research on higher educational careers and the efficiency of students in higher education are true in our sample of the instructors' international mobility. Based on the inquiries of Engler (2016; 2015a; 2015b, 2018), Perna (2001), Sax et al. (2002) we presumed that since the supportive family background influences the learning productivity of adults in higher education, this would be true for the academic competences of the instructors as well, even if the effect in our sample would be an indirect one. It is evident from Table 3 that it is indeed the married or those in a relationship that show stronger international activity, while the singles instructors' is very weak or non-existent. 
Table 3. International activity of instructors based on marital status (\%; $\mathrm{N}=210)$

\begin{tabular}{|c|c|c|c|c|c|}
\hline marital status * & 0 & 1 & 2 & 3 & 4 \\
\hline single & $\underline{36,8}$ & 15,8 & 21,1 & 13,2 & 13,2 \\
\hline married/in a rel. & 9,7 & 21,4 & 22,1 & $\underline{31,2}$ & 15,6 \\
\hline divorced & 0 & $\underline{50}$ & 25 & 12,5 & 12,5 \\
\hline
\end{tabular}

The level of significance of connection: ${ }^{*} p<0,05$. The underlined values point to the fact that considerably more instructors ended up in these cells than what would have been in case of a random arrangement. We removed the „widowed" category from the analysis, since in our sample there were only two instructors like that.

According to the field of study we also found significant differences: the Faculty of Humanities stood out the most, this was the field where there were the least instructors with a low activity index, and where there were the most with the strongest activity index.

Table 4. International activity of instructors based on field of study (\%; $\mathrm{N}=210)$

\begin{tabular}{cccccc}
\hline field of study * & $\mathbf{0}$ & $\mathbf{1}$ & $\mathbf{2}$ & $\mathbf{3}$ & $\mathbf{4}$ \\
\hline FM & $\underline{\mathbf{1 8 , 3}}$ & 19,7 & 16,9 & $\mathbf{3 6 , 6}$ & 8,5 \\
FH & 7,5 & 23,9 & 23,9 & 19,4 & $\underline{\mathbf{2 5 , 4}}$ \\
RKC & $\underline{\mathbf{1 7 , 4}}$ & 21,7 & 24,6 & 23,2 & 13 \\
\hline
\end{tabular}

The level of significance of connection ${ }^{*}: p<0,05$. The underlined values point to the fact that considerably more instructors ended up in these cells than what would have been in case of a random arrangement.

In Viszt's (2004) research we see that there are major dissimilarities based on the field of study. The most mobile are the social scientist; per capita, outward travels are the highest in this group. They are also the ones who choose the longer trips (more than 20 days annually). The representatives of the humanities are lagging behind by 5-10 days in a year. This may seem to contradict our findings, but in our case the Faculty of Humanities at the investigated higher educational institution involves social sciences as well. When we broke down the category even more, we came to the same conclusion as Viszt, namely that social scientists' international activity is the strongest in the sample.

In the Norwegian research though, all of disciplines represent themselves in a relatively even proportion, there is not one domineering field. This can be explained by the fact that while in most northern European countries academics can go on a sabbatical year, in Hungary that is not a tradition at universities, thus the northern colleagues seem to be less pressured by the internationalization that takes place in higher education. Furthermore, Hungarian researchers believe that, unlike Hungary, in Norway every discipline has equal opportunity in the efficient national scholarship system, and, as a result of international mobility, financial conditions are also considered to be far better. However, Smeby and Trondal (2005) too, in their study, had a theory that the different fields of study are on dissimilar international activity levels. They argue that there is a rather definite line between "soft" and "hard" disciplines regarding international mobility. "Hard" sciences like medical or natural sciences tend to be more international than the "soft" ones, like humanities (KyvikLarsen 1997). In their concept "hard" fields of study are less easily influenced by country, society, culture, or regional location.

Our perception is, based on the peculiar political and economic embeddedness and heritage of our country, that it is so much more true in the central- and eastern-European academic context. In the years prior to the Change of Regime (1989) the traveling and applying for scholarships abroad were regulated for academics from certain disciplines. Instructors from the politically and ideologically "safe" fields of study, such as natural or medical sciences, enjoyed a greater freedom in 
academic mobility, especially if the researcher or instructor was "politically reliable". On the other hand, social sciences and humanities were considered "dangerous", not to mention the fact that the translatability of the latter, even today, was more difficult. However, the previous disadvantage, after 1989, served as an excellent basis for building out international connections in the above mentioned fields, as social sciences, as well as humanities made an attempt to exploit the topics and issues of the Change of Regime (Pikó 2003; Fekete-Simándi 2013; Dabney-Fekete 2018).

Following in the footsteps of Viszt's research (2004), we wanted to know what factors the instructors list as the greatest obstacles for them not participating in international mobility. In their inquiry the researchers registered twelve main causes: 1 . lack of language knowledge; 2 . lack of professional experience or knowledge; 3. lack of international cooperation networks; 4. being uninformed; 5 .not knowing how to apply; 6 . lack of motivation; 7. negative experiences; 8 . fear of losing their job; 9. family; 10. disapproval of bosses; 11. disapproval of colleagues; 12 . other. Those among the workers of state-maintained universities blamed the absence of information about projects, family issues and weak international academic ties. Interestingly enough, the lack of sufficient language knowledge was not so emphasized. In our research however, the insufficient knowledge of language stands out, as well as the drawback having a family presents, and financial problems - the latter being especially true in connection with attending conferences. The instructors in our sample said that the registration fee, travel costs, accommodation and food for 5-10 days can add up to spending more than half of a month's salary, which the individual cannot, the institute in many cases will not cover (Dabney-Fekete 2018). Different is the situation in Norway: academics would rather choose attending a conference, since it is more available than, for instance, scholarships, and the energy put into a conference performance is way less than any other type of international mobility (Smeby- Trondal 2005). We also found that many instructors are not motivated to go abroad - partly because they see no chance at getting any kind of support from their own institute, and also because of the hierarchy at their workplace. They feel that the finances and information are distributed on higher levels, thus they only get the "crumbs" from the table of international mobility (Dabney-Fekete 2018).

Browsing through the special literature, the experience is that especially for Hungarians the lack of language knowledge (more specifically: English) constitutes a great problem, although it is crucial to any kind of international activity (Medgyes-Kaplan 2015). In our research we wanted to shed light on whether the instructors' fears of not knowing the lingua franca (enough) is actually mirrored in their language knowledge. We primarily focused not on the language exams, but rather on real profession-oriented language knowledge, and whether the inquired academics are able to use it in their everyday practices. It was unanticipated to see that it was the colleagues from the foreign language departments whose international academic activity was relatively moderate, and that they are the ones who rarely attend international conferences - although their language knowledge and skills would enable them to do so. One of the instructors from the research study stated that the reason behind this phenomenon is that they, due to their proficiency in the given foreign language, count as "special" in the national arena. However, in an environment where everybody is supposed to have that skill, they fear "loss of prestige" if they make for instance a grammatical mistake (DabneyFekete 2018).

\section{Conclusions}

Academic mobility can be seen as a fluid and dynamic entity that is part of a complex sociocultural, political and economic interaction network made up of the knowledge that people gain by participating in it (Danaher-Danaher 2011). It is also an inevitable element of constructing capacity and world-class excellence (Jacob-Meek 2013) due to quality, competitiveness and diversity that this expanding international network brings (Van Der Wende 2015) on local and global levels. That could be a reason for the deliberate and, in most countries very well-organized, national and international policies supporting and promoting this particular type of capacity development. Despite the increasing number of voices in special literature that criticize (some even question) the gains and the 
benefits of academic mobility and claim that there are many less romantic aspects of this mixed blessing (Jacob-Meek 2013), it cannot be denied that it enhances transcultural learning, communication technology, good research infrastructure, intercultural competences, professional prospects and future employability, problem-solving and decision-making capacity, cultural and global awareness. Academic mobility has also grown to mean "visibility" on the international scientific stage: one can only be noticed if they appear at a forum where they can show what they have. It does not only bring strengthened research and teaching abilities, more and better academic outputs and publications but it also helps the instructor to improve their language proficiency (Craciun-Orosz 2018).

In our research (Dabney-Fekete 2018) we made an attempt to uncover the international activity based on the academic mobility of the instructors at two Hungarian higher educational institutions. Concerning the examined discussions, categories and proposed topics, it was built upon two previously carried out investigations (one that collected data from among research centers in Hungary, and the other that aimed to study the mobility of instructors at Norwegian universities). We found that in Hungary in the given time period (2012-2014), the instructors with the strongest international activity were: 1 . the men; 2 . those who held higher academic positions; 3 . those who were married or were in a relationship; and 4 . who were from the field of social science. The latter was in harmony with the findings of Viszt's research (2004) which shows that based on the field of study there are main differences - typically social scientists are the most mobile, and they are also the ones who travel for longer trips. And in that, both Hungarian researches in a way contradict Semby and Trondal's theory of "hard" and "soft" sciences.

We believe that with the help of the international activity index that we created and developed, those who shape and execute the strategies of internationalization, both on the national and local (institutional, faculty and department) levels, will have a broader understanding and better view of the motivation and attitude behind instructors' international activity, which could lead to the formation of more successful and realistic strategic goals.

Funding: This research received no external funding.

Conflicts of Interest: The author declares no conflict of interest.

\section{References}

1. Craciun, D. \& Orosz, K. (2018). Benefits and costs of transnational collaborative partnerships in higher education. Luxembourg: Publications Office of the European Union.

2. Dabney-Fekete, I. D. (2018). Oktatók tudományos együttmúködésének hálózatai a felsőoktatásban. [Academic Networks of Cooperation of Instructors in Higher Education]. Doctoral dissertation. University of Debrecen.

3. Danaher, P. A \& Danaher, G. R. (2011). Mobile Learning Communities: Lessons for and from Academic Mobility, the Knowledge Economy and Sustainability. In Dervin, F. (Ed.). Analysing the Consequences of Academic Mobility and Migration. Cambridge: Cambridge Scholars Publishing. 131-146.

4. Dusa Á. R. (2017). A hallgatói mobilitás mint a nemzetköziesedés célja és eszköze. [International student mobility as the goal and tool of internationalization.] University of Debrecen HTDI. Doctoral dissertation.

5. Enders, J. \& Fulton, O. (2002). Blurring Boundaries and Blistering Institutions. In Enders, J. \& Fulton, O. (Eds). Higher Education in a Gobalising World. London: Kluwer Academic Publishers. 1-14.

6. Enders, J. (2004). Higher education, internationalisation and the nation-state: Recent developments and challenges to governance theory. Higher Education, 47(3), 361-382.

7. Enders, J. \& Teichler U. (1995). Der Hochschullehrerberuf im internationalen Vergleich. Bonn: Bundesministerium für Bildung, Wissenschaft, Forschung und Technologie.

8. Engler, Á. (2015a). A család szerepe az eredményes életpálya kialakításában. [The role of the family in forming an efficient career] Kapocs: A nemzeti család-és szociálpolitikai intézet folyóirata, 14(2), 29-37.

9. Engler, Á. (2015b). The effect of student's commitment on career. In Pusztai, G. \& Ceglédi, T. (Eds). Professional Calling in Higher Education: Challenges of Teacher Education in the Carpathian Basin. Nagyvárad: Új Mandátum. 167-174. 
10. Engler, Á. (2016). A gyermeknevelés szakmai életútra gyakorolt pozitív hatásai. [The positive effects of raising a child on professional career] Szociálpolitikai Szemle, 2(1), 65-77.

11. Engler Á. (2018). A család mint erőforrás. [The family as resource] Budapest: Gondolat Kiadó.

12. European Comission (1997). European Report on Science \& Technology Indicators. Brussels: European Comission.

13. Fekete, I. D. \& Simándi, Sz. (2013). International Academic Relations in Central and Eastern Europe - a Brief Comparative Approach. In Juhász, E. (Ed.). Education in Transition. Váhom, Slovakia: Dubnicky technologicky institute v Dubnici nad. 55-64.

14. Jacob, M. \& Meek, L. (2013). Scientific mobility and international research networks: trends and policy tools for promoting research excellence and capacity building. Studies in Higher Education, 38(3), 331-344.

15. Hakala, J. (1998). Internationalisation of science. Views of the scientific elite in Finland. Science Studies 11(1), 52-74.

16. Kakihara, M. \& Sorensen, C. (2002). Post-modern professionals' work and mobile technology. [Paper presented at the 25th Information Systems Research Seminar in Scandinavia, Copenhagen Business School, Frederiksberg, Denmark.]

17. Knight, J. (2003). Updating the Definition of Internationalization. International Higher Education, 33(Fall), 2-3.

18. Knight, J. (2013). The changing landscape of higher education internationalisation - for better or worse? Perspectives: Policy and Practice in Higher Education, 17(3), 84-90.

19. Knight, J. \& De Witt, H. (2018). Internationalization of Higher Education: Past and Future. International Higher Education, 95(Fall), 2-4.

20. Kozma T. \& Fényes H. \& Tornyi Zs. Zs. (2007). Negyvenheten: Gyorskép a neveléstudományi felsőoktatókról és kutatókról. [47: A glance at researchers and instructors in educational science] Educatio, 16 (3), 418-433.

21. Kyvik, S. \& Larsen, I. M. (1997). The exchange of Knowledge. A small country in the international research community. Science Communication, 18(3), 238-264.

22. Luukkonen, T. \& Persson, O. \& Sivertsen, G. (1992). Understanding patterns of international scientific collaboration. Science, Technology \& Human Values, 17(1), 101-138.

23. Medgyes, P. \& Kaplan R. B. (2015): A magyar kutatók idegennyelv-tudása. [Foreign language knowledge of Hungarian researchers] In Medgyes P. (Ed.). Töprengések a nyelvtanításról. Budapest: Eötvös Kiadó. 65-78.

24. Meyer, M. (2010). The Rise of the Knowledge Broker. Science Communication. SAGE Publications, 32 (1), 118127.

25. Morley, L. \& Alexiadou, N. \& Garaz, S. \& González-Monteagudo, J. \& Taba, M. (2018). Internationalisation and migrant academics: the hidden narratives of mobility. Higher Education, 76(3), 537-554.

26. O'Hara, S. (2009). Internationalizing the Academy: The Impact of Scholar Mobilty. In Bhandari, R. \& Shepherd, L. (Eds): Higher Education on the Move: New Developments in Global Mobility. New York: HE. 29-48.

27. Papanek G. (2006). Tudásáramlás, jogbiztonság, együttmúködés: A magyar gazdaság fejlódésének láthatatlan forrásai. [Knowledge flow, legal certainty, cooperation: The invisible sources of the development of Hungary's economy.] Budapest: Aula Kiadó.

28. Perna, L. W. (2001). The relationship between family responsibilities and employment status among college and university faculty. The Journal of Higher Education, 72(5), 584-611.

29. Pikó, B. (2003). Tudósszerepek és megnyilvánulások a rendszerváltozás után - Korlátok és lehetőségek. [Academic roles and manifastations after the Change of Regime - Limits and Possibilities] Világosság, 44(910), 169-175.

30. Pusztai G. (szerk.) (2007). Új társadalmi kockázatok az európai tudástársadalomban és felsőoktatásban a szakemberekkel készült interjúk tükrében. [New social risks in the knowledge society and in higher education in the light of the interviews made with experts] http://cherd.unideb.hu/NESOR\%20CHERD\%20Report\%202.0.pdf (2008.02.12.).

31. Pusztai, G. \& Fekete, I. D. \& Dusa, Á. R. \& Varga, E. (2016). Knowledge brokers in the heart of Europe: International Student and Faculty Mobility in Hungarian Higher Education. Hungarian Educational Research Journal, 6(1), 58-73.

32. Sax, L. J. \& Hagedorn, L. S. \& Arredondo, M. \& Dicrisi III F. A. (Eds) (2002). Faculty research productivity: exploring the role of gender and family-related factors. Research in Higher Education, 43(4), 423-446. 
33. Schneider, N. (2009). Az európai családok sokfélesége. [The diversity of European families] Demográfia, 52(4), 267-282.

34. Siekierski, P. \& Lima, M. C. \& Borini, F. M. (2018). International Mobility of Academics: Brain Drain and Brain Gain. European Management Review, 15(3), 329-339.

35. Simmel, G. (1922). Conflict and the Web of Group Affiliations. Translated and edited by Kurt Wolff. Glencoe, IL: Free Press.

36. Smeby, J.-C. \& Gornitzka, Å. (2008): All cosmopolitans now? The changing international contacts of university researchers. In Gornitzka, Å. \& Langfeldt, L. (Eds). Borderless knowledge: Understanding "new" internationalisation of research and higher education in Norway. Dordrecht: Springer. 37-50.

37. Smeby, J-C. \& Trondal J. (2005): Globalisation or europeanisation? International contact among university staff. Higher Education, 49, 449-466.

38. Van Der Wende, M. (1997). International comparative analysis and synthesis. In Kälvemark, T., van der Wende, M. (Eds.). National Policies for the Internationalisation of Higher Education in Europe. Stockholm: National Agency for Higher Education. 225-258.

39. Viszt, E. (2004). A kutatók nemzetközi mobilitása. [International Mobility of Researchers] Magyar Tudomány, 49(8), 886-899.

2020 by the author. Submitted for possible open access publication under the terms and conditions of the Creative Commons Attribution (CC BY) license (http://creativecommons.org/licenses/by/4.0/). 